\title{
ESTÉTICA DE LA POESÍA RABIOSA
}

Martín Alvarenga

\section{IMAGINACIÓN POÉTICA}

Podriamos decir que la poesia es una trayectoria lanzada hacia el misterio. Se trata de una exploración a mundos ignotos, una experimentación vital a través de la trama del lenguaje.

Es inútil definir la poesia, pero vale señalar su presencia dinámica, estremecedora, envolvente. Aunque no sepamos en el fondo de qué se trata, la poesía está ahí, con su evidencia, más allá de toda excusa y de toda significación.

Si nos interesa la poesía, nos interesa el centro energético de la vida, instalada en la criatura humana. Si nos interesa la poesía, nos interesa desde ya la creación a través de la palabra, un territorio en el cual nos recreamos en el movimiento pendular del miedo y de la audacia, de lo pavoroso y lo maravilloso, de lo doloroso y de lo extático.

La poesía en el poema y fuera del poema como experiencia interna y como comunicación en la aventura de vivir, una forma de abordar la existencia apostando a la mayor inversión de sentido. La experiencia poética como trueque de aventuras, como intercambio de fronteras.

La poesía, en la fluida cápsula del poema, es la quintaesencia del idioma, del idioma lanzado al frenesí de su límite.

Pero vale apuntar esta experiencia totalizadora en la dimensión del hombre cotidiano, portador del lenguaje habitual, que subliminalmente deja escapar en el ejercicio del idioma el milagro de la metáfora: "De tu conciencia brota el sol interior". La metáfora surge del diálogo y de la escritura como la luz que purifica una visión. que sacraliza un pensamiento en el territorio de lo literario y de lo no literario.

El mundo real y los signos, el mundo mágico y los símbolos, nacen del pensamiento y se tensionan en la inspiración y la efusión poéticas. El lenguaje de los sueños, de las profecías y de las visiones nos atrapa desde el abismo del imaginario y nos devuelve a nuestro ser original, único, irrepetible.

Deciamos que la certeza poética se autosustenta en la evidencia. Es un conocimiento no demostrable, simplemente acontece, manifestándose. En poesía se expone, se desnuda, no se demuestra.

Ezra Pound postuló al poema como la más alta concentración de sentido, Heidegger habló sobre la desocultación del ser, Benedetto Croce planteó de algún modo que es la sustancia misma de la lengua.

Nos encontramos entonces con que la literatura en general y la poesía en particular ofician de vías de comunicación, de empatía, de seducción. La red simpática se instala en la dupla poeta-lector y repercute en la sociedad y en el universo. 
Desde que el hombre fue hombre necesitó soñar y el lenguaje fue el instrumento de sus sueños. La cosa estaba en trabajar la imaginación desde el mundo de las epifanias, del rapto onírico y de los misterios.

Pero también tenemos que entender la experiencia poética no únicamente como fenómeno existencial, debemos comprenderla como fenómeno social. Con la cultura, con la poesía, con la literatura, despertaremos a una sociedad más plena. Podemos poner toda nuestra carga mental a la intensidad como personas y como comunidad. No en vano Henry Miller y Herbert Read coincidian en "La vida como obra de arte", o Lautreamont deslizaba la frase: "La poesía debe ser hecha por todos".

Podemos expresar en este punto que el poema es una realidad de segundo grado, más auténtica que la realidad misma. El poema es y engendra una verdad interior, una verdad que se manifiesta en lo más oscuro y profundo del sujeto. Es un documento vivo de intersubjetividad y de apelación ante la finitud y la temporalidad.

Hacer poesía en el poema es saltar al vacío superando la parálisis, la depresión, la alienación.

El poema es un movilizador a partir de la pasión, a partir de la inteligencia de los sentimientos. Por más intelectual, por más frío que parezca un poema éste se halla avalado y construido desde el núcleo de los sentimientos.

El poeta no es un sujeto aislado, está íntimamente involucrado en la red social. No está en la torrre de marfil ni en la trinchera neurótica de la inmediatez. Está en la vida. Más aún, está al borde de la vida.

El lector, cuando lee un poema o cuando tiene la experiencia interna de la poesía, es el cómplice del poeta en ese cruce de fronteras hacia lo imposible, en esa trayectoria en donde ignorancia y sabiduría son la manifestación de la plenitud de la criatura humana.

\section{TRANSGRESIÓN Y COMUNIÓN}

La herramienta del poeta es el lenguaje, el lenguaje como punto de partida para una tenaz conversión del mundo convencional. El poeta tiene hambre de sobrenaturalidad, de universos inexplorados; el poeta tiene hambre de locura, de disparate, de adivinación, el poeta arranca de la realidad cotidiana y la jerarquiza en los valores de lo bello y lo sagrado.

Pero la conversión del lenguaje y su jerarquización existen gracias a un código emergente de un tejido simbólico vuelto sobre sí, que es el brotar mismo de la poesía, su naturaleza y sus misterios. $Y$ también merced al lector, ese otro gran protagonista de la recreación del discurso, al lector como confidente y como secuaz de los padecimientos y los goces que engendra la función poética.

La poesía es una ideología sanguínea, es un modo de mirar abierto, despojado y a la vez pudoroso; es participar en el mundo con el apetito del religamiento, de la fusión absoluta de lo uno y lo múltiple.

La poesia -como consagración y transgresión en la escritura y la oralidadcoloca a lo humano en un íntimo y evasivo diálogo con el Ser, preñado de interrogaciones, dudas, rechazos e intensas identificaciones.

¿ Por qué es rabiosa la poesía? La poesía es rabiosa por reconocerse rebelión, ternura, sabiduría y comunión. Se torna lenguaje subversivo, pensamiento anárquico, 
conducta sentimental en medio de almas que se han convertido en vidriera abarrotada de mercancías, en valor de trueque en un mundo enajenado por el brillo, por el consumo, por el estatus y la impunidad.

La poesía es extraída como un hijo del vientre de su madre y viene al mundo entre el grito, el júbilo, el desamparo y el silencio.

La poesía es sentido, precipitación, vuelo y peregrinación terrestre. Es exponerse el riesgo de saber quiénes somos al tiempo de desconocer la proyección de nuestra silueta en el espejo quebradizo de la vida.

\section{POESÍA RABIOSA}

La poesia rabiosa busca la inocencia a través de una belicosidad necesaria. Se trata de tomar la metáfora como arma y defender con ella la vida contra la muerte, por la vía legítima de los sueños y de las visiones. Poesía rabiosa, memoria y profecía, sonrisa vertical y oblicua, drogada por la luz, cadáver exquisito y resucitado, máquina de coser con alas.

Rabia poética, transgresora. Rabia con ternura, ira con amor, cólera compasiva, delicada hidrofobia contra la hipocresia.

Poesía rabiosa, feeling metafísico, mano tridimensional, el grado cero de la escritura en la desnudez desnuda de la palabra. Poesía rabiosa, magia simpática, precisión lírica en el arrebato del éxtasis luminoso.

La cólera justiciera de la poesía se ubica en el horizonte de lo absoluto; es la libetad fuera de toda discusión, en la rebeldía y en la revolución; es la luna del mediodía y el sol de medianoche, es el estado salvaje de la levitación.

Poesía rabiosa, emoción arrancada de sí, cuerpo sin piel y poesía sin piel padeciendo la locura del mundo, la saludable locura de la iluminación.

Poesía rabiosa, río de imágenes, poesía ternura, descubrimiento, asombro, admiración e invención.

Poesía en el poema, palabra electrizada en la contemplación del universo, el universo en su desamparo, el universo en su potencia creadora.

Poesía rabiosa, Navidad del poema, crucifixión del poema, renacimiento de la palabra desde la energía del cuerpo, el cuerpo que se anima e inspira, el cuerpo que se abre al temblor de la realidad, a la fluyente maravilla del misterio.

Poesía rabiosa, pedacito de temura, átomo semántico y enceguecedora linterna que nos devuelve la visión interior, la que nos permite ser libres y solidarios, lúcidos y fraternos, cuerdos y locos, dioses y hombres, ángeles y demonios.

Poesía rabiosa, principio y fin del pensamiento, grado cero de la imaginación que comienza a contener todo el sentido, el valor y el milagro eterno de la palabra.

\section{MARATÓN DE LA POESÍA RABIOSA}

Es atractivo ponerle dinamita al conocimiento, es subyugante ponerle una bomba fantástica al conocimiento cotidiano.

Es seductor orientarse hacia una poética de la imagen, hacia un deporte del símbolo, hacia una maratón rabiosa de la poesía. La poesía no sólo en la escritura, la poesía fluyendo locamente en el pensamiento y en el cuerpo. 
Descubrir la loca poesía es diseñar un aerostato para ver desde arriba que el mundo es un garbanzo en la infinita plantación del cosmos.

Descubrir la metáfora es hallar una vía de escape de la prisión convencional al reino de las transgresiones, de las utopias, de los bienaventurados erotismos, sensaciones, visiones y meditaciones.

Una maratón de poesía rabiosa desborda el escenario de la representación e invade el escenario de la historia, con sus sabores de agonia, de goce y de incertidumbre.

La poesia, siendo consustancial al hombre, lleva en si su temblor, su firmeza, sus miedos, sus desesperaciones y su sed de eternidad y de infinito.

Cuando la poesía se pone en movimiento, el mundo comienza a despertar y canta el himno de la vida que seduce y enamora a los humanos que han captado la melodía del universo.

Una maratón de poesía rabiosa, de poesía tierna y violenta, de poesía trágica y extática nos devuelve a la inocencia, a la humildad, a la sencillez del universo.

La poesía no es el poema, la poesía no es la poesía, la poesia es el silencio que abraza la emoción para que ésta persiga furiosamente la milagrosa inutilidad y el heroico sinsentido de ser hombre, de ser hombre sin equipaje y sin puerto, con el único cable que le arroja la naturaleza: un camino sin final y sin comienzo que se proyecta hacia el río de los sueños y de las visiones.

La poesía rabiosa es un juguete tierno para comer.

La poesía es un salto mortal a lo desconocido , a lo innombrable que es capturado por el milagro de la palabra, por el vuelo rabioso de la humanidad. 